Review

\title{
Pre-Clinical Cell-Based Therapy for Limbal Stem Cell Deficiency
}

\section{Amer Sehic ${ }^{1}$, Øygunn Aass Utheim ${ }^{2}$, Kristoffer Ommundsen ${ }^{3}$ and Tor Paaske Utheim ${ }^{1,3, *}$}

1 Department of Oral Biology, Faculty of Dentistry, University of Oslo, Sognsvannsveien 10, Oslo 0372, Norway; E-Mail: amer.sehic@odont.uio.no

2 Department of Ophthalmology, Oslo University Hospital, Kirkeveien 166, Oslo 0407, Norway; E-Mail: outheim@gmail.com

3 Department of Medical Biochemistry, Oslo University Hospital, Kirkeveien 166, Oslo 0407, Norway; E-Mail: kristoffer@ommundsen.com

* Author to whom correspondence should be addressed; E-Mail: utheim2@gmail.com.

Academic Editor: Dimitrios Karamichos

Received: 20 July 2015 / Accepted: 21 August 2015 / Published: 28 August 2015

\begin{abstract}
The cornea is essential for normal vision by maintaining transparency for light transmission. Limbal stem cells, which reside in the corneal periphery, contribute to the homeostasis of the corneal epithelium. Any damage or disease affecting the function of these cells may result in limbal stem cell deficiency (LSCD). The condition may result in both severe pain and blindness. Transplantation of ex vivo cultured cells onto the cornea is most often an effective therapeutic strategy for LSCD. The use of ex vivo cultured limbal epithelial cells (LEC), oral mucosal epithelial cells, and conjunctival epithelial cells to treat LSCD has been explored in humans. The present review focuses on the current state of knowledge of the many other cell-based therapies of LSCD that have so far exclusively been explored in animal models as there is currently no consensus on the best cell type for treating LSCD. Major findings of all these studies with special emphasis on substrates for culture and transplantation are systematically presented and discussed. Among the many potential cell types that still have not been used clinically, we conclude that two easily accessible autologous sources, epidermal stem cells and hair follicle-derived stem cells, are particularly strong candidates for future clinical trials.
\end{abstract}

Keywords: biomaterials; cornea; ex vivo cultivation; limbal stem cell deficiency; ocular surface disease; transplantation 


\section{Cornea and Limbal Stem Cells}

The cornea is the anterior, transparent, and avascular tissue with high refractive power that directs light bundles to the retina [1]. The highly specialized structure of the cornea is essential for normal vision. From anterior to posterior, the cornea is composed of five layers, i.e., epithelium, Bowman's membrane, stroma, Descemet's membrane, and endothelium. The corneal epithelium is composed of a basal layer of column-shaped cells, a suprabasal layer of cuboid wing cells, and a superficial layer of flat squamous cells [2]. The thickness of the corneal epithelium in different species, e.g., human, mouse, and rabbit, is conspicuously perpetual, ranging from 45 to $50 \mu \mathrm{m}$ [3-5]. The renewal of corneal epithelium differs between species and is renewed every 9-12 months in rabbits [6]. The corneal epithelium plays an essential role in maintaining the cornea's avascularity and transparency [7].

The self-renewing properties of the corneal epithelium are an important requirement for corneal integrity and function [8]. This process is dependent on a small population of limbal stem cells that are situated in the basal region of the limbus $[9,10]$. Limbal stem cells are presented in the basal layer of the limbal epithelium and give rise to fast-dividing, transient amplifying cells [11]. Transient amplifying cells go through a restricted number of divisions before becoming terminally differentiated cells [12]. It has been hypothesized that corneal epithelial maintenance can be defined by the equation $X+Y=Z$, in which $X$ refers to proliferation of basal cells; $Y$ is the centripetal movement of peripheral cells; and $Z$ is the epithelial cell loss from the corneal surface [13].

\section{Limbal Stem Cell Deficiency}

Any process or disease that results in dysfunction or loss of the limbal epithelial cells (LEC) may result in limbal stem cell deficiency (LSCD) [7]. In LSCD, the conjunctival epithelium migrates across the limbus, resulting in loss of corneal clarity and visual impairment. The condition is painful and potentially blinding [14]. Normal and well-functioning LEC act as an important barrier, preventing invasion of the cornea by conjunctival tissue. Limbal stem cell deficiency typically worsens over time since chronic inflammation not only results in the death of LEC, but also negatively affects the remaining stem cells and their function [14].

The prevalence and incidence of LSCD worldwide are not known. In India, the prevalence is estimated to be approximately 1.5 million [15], and the incidence in North America is estimated to be "thousands" [16]. The etiology of many cases of LSCD is known; however, idiopathic cases also exist [17,18]. Acquired causes of LSCD include thermal and chemical burns of the ocular surface, contact lens wear, ultraviolet radiation, extensive cryotherapy, or surgery to the limbus [7]. There are also numerous hereditary causes of LSCD, including aniridia, where the anterior segment of the eye including the limbus is imperfectly developed. Furthermore, autoimmune diseases involving the ocular surface, e.g., Stevens-Johnson syndrome and ocular cicatricial pemphigoid, are examples of nonhereditary causes of LSCD.

Limbal stem cell deficiency is classified as either partial or total, depending on the extent of the disorder. Conjunctivalization is pathognomonic for LSCD. Other signs are persistent epithelial defects, superficial and deep corneal vascularization, and fibrovascular pannus. Limbal stem cell deficiency in patients with significantly dry eyes results in a partial or total keratinized epithelium [19]. The diagnosis 
can be corroborated by detection of conjunctival cells on the corneal surface by cytological analysis [20] or in vivo confocal microscopy [21], but is seldom performed as the diagnosis is often obvious.

\section{Treatment Approaches for Limbal Stem Cell Deficiency}

The core of conservative treatment for LSCD lies in the improvement of epithelial healing. A range of clinical procedures, with distinctive benefits and limitations, are currently available for treating LSCD. However, variations in both the severity and causes of LSCD explain why the application of one treatment approach will not be adequate for all. A great variety of cell-based therapeutic strategies have been suggested for LSCD over the past 10 years. In cases of partial LSCD, amniotic membrane (AM) can be applied to the affected eye and aids in repopulating the ocular surface with corneal epithelium [22]. With increased understanding of the origin of the stem cells in the limbus [10], the transplantation of limbal grafts was introduced in 1989 [23], a promising treatment strategy for restoring the ocular surface following LSCD. This procedure, however, carried a risk of inducing LSCD in the healthy eye due to the need of large limbal biopsy, making the therapy impossible in cases of bilateral LSCD.

In 1997, a groundbreaking therapeutic strategy involving ex vivo expansion of LEC was introduced [24]. The principle of this method is to culture LEC harvested from the patient, a living relative, or a cadaver on a substrate in the laboratory and then transfer the cultured tissue onto the eyes of patients suffering from LSCD. This therapy has gained popularity in ophthalmology as it increases cell numbers before transplantation without the need for a large limbal biopsy. It is suggested that the mechanism underlying the improvement in the ocular surface after LEC allograft transplantation is due to the stimulation of a small number of residual dormant host cells, rather than transplanted cells, permanently replacing the ocular surface [25]. Another possibility is that the transplanted graft somehow attends to stimulate progenitor cells in the blood stream to repopulate the ocular surface [25].

Recently, the use of induced pluripotent stem cells (iPSCs) has attracted great attention [26,27]. Following culture for two weeks on an amniotic membrane, limbal iPSCs developed substantially higher expression of several putative limbal stem cell markers, including ABCG2 and $\triangle \mathrm{Np} 63 \alpha$, than did fibroblast iPSCs [27]. The successful generation of iPSCs from human primary LEC, and subsequent re-differentiation back to the limbal corneal epithelium, has been demonstrated in vitro [27]. However, IPSCs have so far not been used in clinical studies or experimental animals for ocular surface reconstruction, despite the great promise this treatment holds.

Since 1997, several research groups have shown favorable effects of ex vivo cultured cell therapy for LSCD in both clinical studies and experimental animals. There is currently a strong trend toward applying autologous sources as there is no risk for immunological reactions and, therefore, no requirement for immunosuppressive therapy with all known side effects [28]. Since 2003, several non-limbal cells have been successfully used to reconstruct the corneal epithelium in bilateral LSCD, in which limbal tissue is not recommended for harvest. Among non-limbal cell types, oral mucosal epithelial cells and conjuctival epithelial cells are the only laboratory cultured cell sources that have been explored in humans. Oral mucosal epithelial cells were the first non-limbal cell type to be identified as a potential source for LSCD. So far, 242 patients have been reported to be treated with a success rate of $72 \%$ [29]. Since 2009, conjunctival epithelial cells have also been used with the purpose of reverting LSCD in clinical trials, but the number of patients treated is small [30]. Since 2010, there have been two 
clinical studies including 17 eyes that have used nasal mucosal epithelial cells to treat LSCD with promising results $[31,32]$. In contrast to most of the other cell types that have been used for LSCD therapy, nasal mucosa was transplanted to the eyes without prior ex vivo cultivation, which substantially simplifies the procedure.

A number of other non-ocular cells have been investigated as alternative stem cell sources for treating LSCD; however, they have only been studied in animal experiments. As none of the cell types used in clinical trials have proved to be successful in more than about three of four cases [7,29], there has been a constant search for novel cell types that potentially could be more effective in reverting LSCD. The present review focuses on these cell types. The review was prepared by searching the National Library of Medicine database using the broad search term "limbal" in an attempt not to leave out any relevant publications. In total, the search resulted in 3634 studies, whereof 19 studies, published from 2004 to 2014, were related directly to the core topic of the present review. These studies include the following cultured cell types: (1) bone marrow-derived mesenchymal stem cells (Table 1) [33-40]; (2) embryonic stem cells (Table 2) [41-44]; (3) epidermal stem cells (Table 3) [45-47]; (4) hair follicle-derived stem cells (Table 4) [48]; (5) immature dental pulp stem cells (Table 4) [49,50]; (6) orbital fat-derived stem cells (Table 4) [51]; and (7) umbilical cord stem cells (Table 4) [52]. Various substrates and methods have been applied to culture and transplant these cell sources onto damaged corneas of mice, rats, rabbits, pigs, and goats (Figure 1, Table 5). In the present review, the ability of all these cell sources to treat LSCD is discussed.

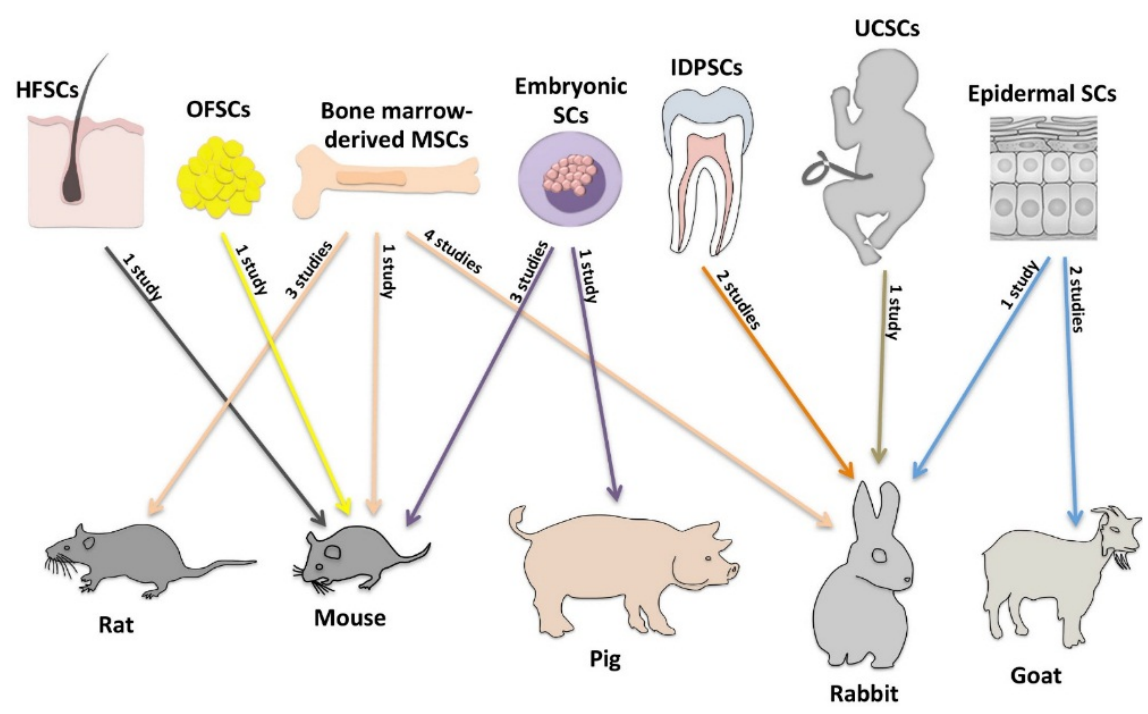

Figure 1. Overview of stem cell sources used in animal experiments. Arrows, including number of studies, indicate the connection between different stem cell sources and LSCD animal models that they have been transplanted to. HFSCs, hair follicle-derived stem cells; MSCs, mesenchymal stem cells; SCs, stem cells; IDPDSCs, immature dental pulp stem cells; OFSCs, orbital fat-derived stem cells; UCSCs, umbilical cord stem cells. 
Table 1. Reconstruction of ocular surface using cultured bone marrow-derived mesenchymal stem cells.

\begin{tabular}{|c|c|c|c|c|c|c|}
\hline $\begin{array}{c}\text { Author, Year, } \\
\text { (Reference) }\end{array}$ & Cell Source & Methods & LSCD Model & $\begin{array}{c}\text { Follow-up } \\
\text { Time } \\
\end{array}$ & Evaluation & Results \\
\hline $\begin{array}{c}\text { Ma et al. } 2006 \\
{[35]}\end{array}$ & $\begin{array}{c}\text { Bone Marrow-Derived } \\
\text { MSCs; Human }\end{array}$ & $\begin{array}{l}\text { Cultured on AM carrier; Transplanted }(n=16) \text {; } \\
\text { Control groups: } 1) \text { transplanted with fibroblast } \\
\text { cells on AM }(n=8) \text { and } 2) \text { transplanted with } \\
\text { only AM }(n=7)\end{array}$ & $\begin{array}{l}\text { Rats; Disc paper } \\
\text { saturated with } 1 \mathrm{~N} \\
\mathrm{NaOH} \text { onto cornea }\end{array}$ & 4 weeks & $\begin{array}{l}\text { Slit lamp } \\
\text { evaluation; } \\
\text { Histology; } \\
\text { IH }\end{array}$ & $\begin{array}{l}\text { Reconstruction in } 100 \%(16 / 16) \text { of animals; } \\
\text { Cornea completely transparent in } 56.3 \%(9 / 16) \\
\text { of animals; Neovascularization detected within } \\
2 \mathrm{~mm} \text { and over } 2 \mathrm{~mm} \text { in } 37.5 \%(6 / 16) \text { and } \\
12.5 \%(2 / 16) \text { of animals, respectively; } \\
\text { No complications }\end{array}$ \\
\hline $\begin{array}{c}\text { Ye et al. } 2006 \\
{[39]}\end{array}$ & $\begin{array}{c}\text { Bone Marrow-Derived } \\
\text { MSCs; Rabbit }\end{array}$ & $\begin{array}{l}\text { Cultured in } \alpha \text {-MEM; IV injection; Four groups: } \\
\text { 1) normal BM function, without MSCs } \\
\text { injection ( } n=15) \text {, } \\
\text { 2) normal BM function, with MSCs injection } \\
(n=15) \text {, } \\
\text { 3) BM suppressed by CP, without MSCs } \\
\text { injection ( } n=15) \text {, } \\
\text { 4) BM suppressed by CP, with MSCs injection } \\
(n=15)\end{array}$ & $\begin{array}{l}\text { Rabbits; Filter paper } \\
\text { saturated with } 1 \mathrm{~N} \\
\mathrm{NaOH} \text { onto cornea }\end{array}$ & 1 month & $\begin{array}{l}\text { Slit lamp } \\
\text { evaluation; } \\
\text { IH }\end{array}$ & $\begin{array}{l}\text { Reconstruction in } 100 \%(15 / 15) \text { of animals in } \\
\text { Group } 2 \text {; } \\
\text { Cornea more clear in group } 2 \text { compared with } \\
\text { other groups; } \\
\text { Neovascularization appeared on day } 14 \text { in } \\
\text { Group } 2 \text {; } \\
\text { No complications }\end{array}$ \\
\hline $\begin{array}{c}\text { Gu et al. } 2009 \\
{[33]}\end{array}$ & $\begin{array}{c}\text { Bone Marrow-Derived } \\
\text { MSCs; Rabbit }\end{array}$ & $\begin{array}{l}\text { Cultured on fibrin carrier; Transplanted }(n=10) \text {; } \\
\text { Control: eyes transplanted with only fibrin graft } \\
\text { gel }(n=10)\end{array}$ & $\begin{array}{l}\text { Rabbits; Cornea } \\
\text { treated with } \\
\text { n-heptanol }\end{array}$ & 4 weeks & $\begin{array}{l}\text { Slit lamp } \\
\text { evaluation; } \\
\text { Histology; } \\
\text { FC; IF }\end{array}$ & $\begin{array}{l}\text { Reconstruction in } 100 \%(10 / 10) \text { of animals; } \\
\text { Iris partially clear in } 30 \%(3 / 10) \text { and } \\
\text { completely obscure in } 70 \%(7 / 10) \text { of animals; } \\
\text { Neovascularization detected over } 3 \mathrm{~mm} \text { from } \\
\text { the limbus in } 80 \%(8 / 10) \text { of animals; } \\
\text { No complications }\end{array}$ \\
\hline $\begin{array}{c}\text { Omoto et al. } 2009 \\
\qquad[36]\end{array}$ & $\begin{array}{c}\text { Bone Marrow-Derived } \\
\text { MSCs; Human }\end{array}$ & $\begin{array}{l}\text { Cultured in } \alpha \text {-MEM; Carrier-free sheets } \\
\text { transplanted; Control: no transplantation; } \\
\text { Number of animals not reported }\end{array}$ & $\begin{array}{l}\text { Rabbits; Cornea } \\
\text { treated with } \\
\text { n-heptanol }\end{array}$ & 4 weeks & $\begin{array}{c}\text { Slit lamp } \\
\text { evaluation; } \\
\text { Histology; } \\
\text { IH; } \\
\text { RT-PCR } \\
\end{array}$ & $\begin{array}{l}\text { Reconstruction of corneal epithelium } \\
\text { successful; } \\
\text { Corneal clarity: no data; } \\
\text { Neovascularization: no data; } \\
\text { No complications }\end{array}$ \\
\hline
\end{tabular}


Table 1. Cont.

\begin{tabular}{|c|c|c|c|c|c|c|}
\hline $\begin{array}{c}\text { Author, Year, } \\
\text { (Reference) }\end{array}$ & Cell Source & Methods & LSCD Model & $\begin{array}{c}\text { Follow-up } \\
\text { Time } \\
\end{array}$ & Evaluation & Results \\
\hline $\begin{array}{c}\text { Jiang et al. } 2010 \\
{[34]}\end{array}$ & $\begin{array}{c}\text { Bone Marrow-Derived } \\
\text { MSCs; Rat }\end{array}$ & $\begin{array}{l}\text { Cultured on AM carrier; Three groups: } \\
\text { 1) transplanted with only AM }(n=12) \text {; } \\
\text { 2) MSCs on AM }(n=12) \text {; } \\
\text { 3) MSCs induced by CSCs on AM }(n=12) \text {; } \\
\text { Control: no transplantation }(n=12)\end{array}$ & $\begin{array}{l}\text { Rats; Filter paper } \\
\text { saturated with } 1 \mathrm{~N} \\
\mathrm{NaOH} \text { onto cornea }\end{array}$ & 10 weeks & $\begin{array}{l}\text { Slit lamp } \\
\text { evaluation; } \\
\text { Histology; } \\
\text { CLCM; } \\
\text { SEM; FC; } \\
\text { IF; IH }\end{array}$ & $\begin{array}{l}\text { Reconstruction in } 75 \%(9 / 12) \text { of animals in } \\
\text { group 3; } \\
\text { Cornea completely transparent in } 75 \%(9 / 12) \text { of } \\
\text { animals; Neovascularization limited within } 2 \\
\text { mm of the limbus; } \\
\text { No complications }\end{array}$ \\
\hline $\begin{array}{c}\text { Zajicova et al. } \\
2010[40]\end{array}$ & $\begin{array}{c}\text { Bone Marrow-Derived } \\
\text { MSCs; Mouse }\end{array}$ & $\begin{array}{l}\text { Cultured on nanofiber scaffold carrier; } \\
\text { Co-transplantation of LSC and MSCs; } \\
\text { Control: normal eyes; Number of animals not } \\
\text { reported }\end{array}$ & $\begin{array}{l}\text { Mice; Epithelial } \\
\text { debridement with } \\
\text { a needle }\end{array}$ & 2 weeks & $\begin{array}{l}\text { Slit lamp } \\
\text { evaluation; } \\
\text { CLCM; FC; } \\
\text { RT-PCR }\end{array}$ & $\begin{array}{l}\text { Significantly inhibited local inflammatory } \\
\text { reactions and supported healing process; } \\
\text { Corneal clarity: no data; } \\
\text { Neovascularization: no data; } \\
\text { No complications }\end{array}$ \\
\hline $\begin{array}{l}\text { Reinshagen et al. } \\
\quad 2011 \text { [37] }\end{array}$ & $\begin{array}{c}\text { Bone Marrow-Derived } \\
\text { MSCs; Rabbit }\end{array}$ & $\begin{array}{l}\text { Cultured in DMEM; Three groups: } \\
\text { 1) MSCs injected under transplanted AM } \\
(n=6) \text {; } \\
\text { 2) transplanted with only AM }(n=5) \text {; } \\
\text { 3) transplanted with AM and autologous LEC } \\
(n=4) \text {, Control: no transplantation }(n=6)\end{array}$ & $\begin{array}{c}\text { Rabbits; Cornea } \\
\text { treated with } \\
\text { n-heptanol }\end{array}$ & 6 months & $\begin{array}{l}\text { Slit lamp } \\
\text { evaluation; } \\
\text { Histology; } \\
\quad \text { IH }\end{array}$ & $\begin{array}{l}\text { Reconstruction in } 100 \%(6 / 6) \text { of animals in } \\
\text { Group } 1 ; \\
\text { Improved corneal clarity; } \\
\text { Neovascularization of the entire cornea in all } \\
\text { animals; } \\
\text { No complications }\end{array}$ \\
\hline $\begin{array}{c}\text { Rohaina et al. } \\
2014 \text { [38] }\end{array}$ & $\begin{array}{c}\text { Bone Marrow-Derived } \\
\text { MSCs; Human }\end{array}$ & $\begin{array}{l}\text { Cultured on AM carrier; Transplanted }(n=4) \text {; } \\
\text { Control groups: } \\
\text { 1) transplanted with only AM }(n=5) \text {; } \\
\text { 2) no transplantation }(n=6)\end{array}$ & $\begin{array}{c}\text { Rats; Disc paper } \\
\text { saturated with } 1 \mathrm{~N} \\
\mathrm{NaOH} \text { onto cornea }\end{array}$ & 8 weeks & $\begin{array}{l}\text { Slit lamp } \\
\text { evaluation; } \\
\text { Histology; } \\
\text { IH; OCT; } \\
\text { RT-PCR }\end{array}$ & $\begin{array}{l}\text { Reconstruction in } 100 \% \text { ( } 4 / 4) \text { of animals; } \\
\text { Moderate corneal clarity; } \\
\text { Minimal vascularization; } \\
\text { No complications }\end{array}$ \\
\hline
\end{tabular}

AM, amniotic membrane; BM, bone marrow; CFE, colony-forming efficiency; CLCM, confocal laser corneal microscopy; CP, cyclophosphamide; CSCs, corneal stromal cells; FC, flow cytometry; IH, immunohistochemistry; IF, immunofluorescence; IV, intravenous; LEC, limbal epithelial cells; LSC, limbal stem cells; LSCD, limbal stem cell deficiency; MSCs, mesenchymal stem cells; OCT, optical coherence tomography; RT-PCR, reverse transcriptase polymerase chain reaction; SEM, scanning electron microscopy. 
Table 2. Reconstruction of ocular surface using cultured embryonic stem cells.

\begin{tabular}{|c|c|c|c|c|c|c|}
\hline $\begin{array}{c}\text { Author, Year, } \\
\text { (Reference) }\end{array}$ & Cell Source & Methods & LSCD Model & $\begin{array}{c}\text { Follow-up } \\
\text { Time } \\
\end{array}$ & Evaluation & Results \\
\hline $\begin{array}{c}\text { Homma et al. } \\
2004 \text { [41] }\end{array}$ & $\begin{array}{l}\text { Embryonic } \\
\text { SCs; Mouse }\end{array}$ & $\begin{array}{l}\text { Cultured on collagen IV-coated plates; } \\
\text { Carrier-free sheets transplanted }(n=10) \text {; } \\
\text { Control: no transplantation }(n=10)\end{array}$ & $\begin{array}{l}\text { Mice; Cornea } \\
\text { treated with } \\
\text { n-heptanol }\end{array}$ & $24 \mathrm{~h}$ & $\begin{array}{c}\text { FC; } \\
\text { Histology; } \\
\text { RT-PCR; WB }\end{array}$ & $\begin{array}{l}\text { Reconstruction in } 100 \%(10 / 10) \text { of animals; } \\
\text { Corneal clarity: no data; } \\
\text { Neovascularization: no data; } \\
\text { No complications }\end{array}$ \\
\hline $\begin{array}{c}\text { Ueno et al. } 2007 \\
{[44]}\end{array}$ & $\begin{array}{l}\text { Embryonic } \\
\text { SCs; Mouse }\end{array}$ & $\begin{array}{l}\text { Cultured on gelatin-coated plates; Transfected with } \\
\text { Pax6; Carrier-free sheets transplanted }(n=5) \text {; } \\
\text { Control groups: } \\
\text { 1) normal eyes }(n=5) \text {; } \\
\text { 2) no transplantation }(n=5)\end{array}$ & $\begin{array}{l}\text { Mice; Cornea } \\
\text { treated with } \\
\text { n-heptanol }\end{array}$ & $24 \mathrm{~h}$ & $\begin{array}{l}\text { Histology; IF; } \\
\text { RT-PCR }\end{array}$ & $\begin{array}{l}\text { Reconstruction in } 100 \%(5 / 5) \text { of animals } 12 \mathrm{~h} \text { after } \\
\text { transplantation; } \\
\text { Corneal clarity: no data; } \\
\text { Neovascularization: no data; } \\
\text { No complications }\end{array}$ \\
\hline $\begin{array}{c}\text { Kumagai et al. } \\
2010 \text { [42] }\end{array}$ & $\begin{array}{l}\text { Embryonic } \\
\text { SCs; } \\
\text { Monkey }\end{array}$ & $\begin{array}{l}\text { Cultured on collagen IV-coated plates; } \\
\text { Carrier-free sheets transplanted }(n=10) \text {; } \\
\text { Control groups: } \\
\text { 1) normal eyes }(n=10) \text {; } \\
\text { 2) no transplantation }(n=10)\end{array}$ & $\begin{array}{l}\text { Mice; Cornea } \\
\text { treated with } \\
\text { n-heptanol }\end{array}$ & $6 \mathrm{~h}$ & $\begin{array}{l}\text { CLCM; IF; } \\
\text { RT-PCR }\end{array}$ & $\begin{array}{l}\text { Transplanted cells adhered to the corneal stroma and } \\
\text { formed multiple cell layers in } 100 \%(10 / 10) \text { of animals; } \\
\text { Corneal clarity: no data; } \\
\text { Neovascularization: no data; } \\
\text { No complications }\end{array}$ \\
\hline $\begin{array}{c}\text { Notara et al. } 2013 \\
{[43]}\end{array}$ & $\begin{array}{l}\text { Embryonic } \\
\text { SCs; Mouse }\end{array}$ & $\begin{array}{l}\text { Cultured on collagen IV-coated plates; } \\
\text { Carrier-free sheets transplanted; } \\
\text { Control: no transplantation; } \\
\text { Number of animals not reported }\end{array}$ & $\begin{array}{c}\text { Pigs; } \\
\text { Epithelial } \\
\text { debridement } \\
\text { with a blade }\end{array}$ & 5 weeks & $\begin{array}{l}\text { Histology; IH; } \\
\text { RT-PCR; WB }\end{array}$ & $\begin{array}{l}\text { Reconstruction after } 1 \text { week; } \\
\text { Corneal clarity: no data; } \\
\text { Neovascularization: no data; } \\
\text { Mild immune reaction }\end{array}$ \\
\hline
\end{tabular}

CLCM, confocal laser corneal microscopy; FC, flow cytometry; IF, immunofluorescence; IH, immunohistochemistry; RT-PCR, reverse transcriptase polymerase chain reaction; SCs, stem cells; SEM, scanning electron microscopy; WB, western blotting. 
Table 3. Reconstruction of ocular surface using cultured epidermal stem cells.

\begin{tabular}{|c|c|c|c|c|c|c|}
\hline $\begin{array}{c}\text { Author, Year, } \\
\text { (Reference) }\end{array}$ & $\begin{array}{c}\text { Cell } \\
\text { Source }\end{array}$ & Methods & LSCD Model & $\begin{array}{c}\text { Follow-up } \\
\text { Time } \\
\end{array}$ & Evaluation & Results \\
\hline $\begin{array}{l}\text { Yang et al. } \\
2007 \text { [47] }\end{array}$ & $\begin{array}{l}\text { Epidermal } \\
\text { SCs; Goat }\end{array}$ & $\begin{array}{l}\text { Cultured on AM carrier; Transplanted }(n=7) \text {; } \\
\text { Control groups: } \\
\text { 1) transplantation with AM }(n=4) \text {; } \\
\text { 2) no transplantation }(n=4)\end{array}$ & $\begin{array}{l}\text { Goats; Excision } \\
\text { of the cornea and } \\
\text { limbus }\end{array}$ & 24 months & IH; SEM; TEM & $\begin{array}{l}\text { Reconstruction in } 100 \% \text { ( } 7 / 7) \text { of animals; } \\
\text { Two or three quadrants of clear cornea in } 71.4 \%(5 / 7) \text { of } \\
\text { animals at follow-up time to } 24 \text { months; } \\
\text { Minimal neovascularization; } \\
\text { Perforation through the pupil during operation in one eye }\end{array}$ \\
\hline $\begin{array}{l}\text { Yang et al. } \\
2008 \text { [46] }\end{array}$ & $\begin{array}{l}\text { Epidermal } \\
\text { SCs; Goat }\end{array}$ & $\begin{array}{l}\text { Cultured on AM carrier; Transplanted }(n=10) \text {; } \\
\text { Control groups: } \\
\text { 1) transplanted with only AM }(n=8) \text {; } \\
\text { 2) no transplantation }(n=8)\end{array}$ & $\begin{array}{l}\text { Goats; Excision } \\
\text { of the cornea and } \\
\text { limbus; Burned } \\
\text { with } 1 \mathrm{~N} \mathrm{NaOH}\end{array}$ & 30 months & $\begin{array}{c}\text { Digital camera; } \\
\text { Histology; IH }\end{array}$ & $\begin{array}{l}\text { Reconstruction in } 100 \%(10 / 10) \text { of animals; } \\
\text { Three or four quadrants of clear cornea in } 80 \%(8 / 100) \text { of } \\
\text { animals at follow-up time to } 30 \text { months; } \\
\text { Minimal neovascularization; } \\
\text { No complications }\end{array}$ \\
\hline $\begin{array}{c}\text { Ouyang et al. } \\
2014 \text { [45] }\end{array}$ & $\begin{array}{c}\text { Epidermal } \\
\text { SCs; } \\
\text { Human }\end{array}$ & $\begin{array}{l}\text { Cultured on fibrin carrier; Transduction of Pax6 } \\
\text { converted these cells into LSC-like cells; } \\
\text { Transplanted and covered with AM }(n=5) \text {; } \\
\text { Control: transplanted with only AM }(n=4)\end{array}$ & $\begin{array}{l}\text { Rabbits; } \\
\text { Excision of the } \\
\text { cornea and } \\
\text { limbus }\end{array}$ & 3 months & $\begin{array}{l}\text { CLCM; IF; } \\
\text { Microarrays; } \\
\text { Quantitative PCR; } \\
\text { RNA-sequencing; } \\
\text { WB }\end{array}$ & $\begin{array}{l}\text { Reconstruction in } 100 \%(5 / 5) \text { of animals; } \\
\text { Transparent cornea in } 100 \%(5 / 5) \text { of animals for over } 3 \\
\text { months; Minimal neovascularization; } \\
\text { No complications }\end{array}$ \\
\hline
\end{tabular}

AM, amniotic membrane; CLCM, confocal laser corneal microscopy; IF, immunofluorescence; IH, immunohistochemistry; LEC, limbal epithelial cells; LSC, limbal stem cells; LSCD, limbal stem cell deficiency; PCR, polymerase chain reaction; SCs, stem cells; SEM, scanning electron microscopy; TEM, transmission electron microscopy; WB, western blotting. 
Table 4. Reconstruction of ocular surface using cultured immature dental pulp stem cells, hair follicle-derived stem cells, umbilical cord stem cells, and orbital fat-derived stem cells.

\begin{tabular}{|c|c|c|c|c|c|c|}
\hline $\begin{array}{c}\text { Author, Year, } \\
\text { (Reference) }\end{array}$ & $\begin{array}{c}\text { Cell } \\
\text { Source } \\
\end{array}$ & Methods & LSCD Model & $\begin{array}{c}\text { Follow-up } \\
\text { Time }\end{array}$ & Evaluation & Results \\
\hline $\begin{array}{l}\text { Monteiro et al. } \\
\quad 2009[50]\end{array}$ & $\begin{array}{l}\text { IDPSCs; } \\
\text { Human }\end{array}$ & $\begin{array}{l}\text { Cultured on AM carrier; Transplanted }(n=5) \text {; } \\
\text { Control: transplanted with only AM }(n=5)\end{array}$ & $\begin{array}{l}\text { Rabbits; Chemical } \\
\text { burn of the cornea }\end{array}$ & 3 months & $\begin{array}{l}\text { Slit lamp } \\
\text { evaluation; } \\
\text { CLCM; IF; } \\
\text { RT-PCR }\end{array}$ & $\begin{array}{l}\text { Reconstruction in } 100 \%(5 / 5) \text { of animals; } \\
\text { Gradual improvement in corneal transparency in } 100 \% \\
(5 / 5) \text { of animals during follow-up time of } 3 \text { months; } \\
\text { Neovascularization: no data; } \\
\text { No complications }\end{array}$ \\
\hline $\begin{array}{c}\text { Gomes et al. } 2010 \\
\text { [49] }\end{array}$ & $\begin{array}{l}\text { IDPSCs; } \\
\text { Human }\end{array}$ & $\begin{array}{l}\text { Cultured on AM carrier; } \mathrm{MCB}(n=5), \mathrm{SCB} \\
(n=4) \text {; Transplanted and covered with AM; } \\
\text { Control: transplanted with only AM }(n=6)\end{array}$ & $\begin{array}{l}\text { Rabbits; Filter paper } \\
\text { saturated with } 0.5 \mathrm{M} \\
\mathrm{NaOH} \text { for } 25 \mathrm{~s} \\
\text { (MCB), and for } 45 \mathrm{~s} \\
\text { (SCB) }\end{array}$ & 3 months & $\begin{array}{l}\text { Slit lamp } \\
\text { evaluation; EM; } \\
\text { Histology; IH }\end{array}$ & $\begin{array}{l}\text { Reconstruction in } 100 \%(5 / 5) \text { of animals; Less } \\
\text { organized and loose corneal epithelium in } 75 \%(3 / 4) \text { of } \\
\text { SCB animals; } \\
\text { Improved corneal clarity in } 100 \%(5 / 5) \text { of MCB } \\
\text { animals; } \\
\text { Superficial neovascularization in one animal } \\
\text { No complications }\end{array}$ \\
\hline $\begin{array}{l}\text { Meyer- } \\
\text { Blazejewska et al. } \\
2011[48]\end{array}$ & $\begin{array}{l}\text { HFSCs; } \\
\text { Mouse }\end{array}$ & $\begin{array}{l}\text { Cultured on fibrin carrier; Transplanted }(n= \\
31) \text {; } \\
\text { Control: no transplantation }(n=31)\end{array}$ & $\begin{array}{l}\text { Mice; Cornea and } \\
\text { limbus removed }\end{array}$ & 5 weeks & $\begin{array}{l}\text { Slit lamp } \\
\text { evaluation; } \\
\text { Histology; IF }\end{array}$ & $\begin{array}{l}\text { Reconstruction in } 87.5 \%(7 / 8) \text { of animals after two } \\
\text { weeks } \\
\text { Improved corneal clarity; } \\
\text { Neovascularization in } 12.5 \%(1 / 8) \text { of animals; } \\
\text { No complications }\end{array}$ \\
\hline $\begin{array}{c}\text { Reza et al. } 2011 \\
{[52]}\end{array}$ & $\begin{array}{l}\text { UCSCs; } \\
\text { Human }\end{array}$ & $\begin{array}{l}\text { Cultured on AM carrier; Three groups: } \\
\text { 1) transplanted cell sheets on AM }(n=6) \text {; } \\
\text { 2) transplanted with only AM; } \\
\text { 3) no transplantation }\end{array}$ & $\begin{array}{l}\text { Rabbits; Cornea and } \\
\text { limbus removed }\end{array}$ & 4 weeks & $\begin{array}{c}\text { Slit lamp } \\
\text { evaluation; } \\
\text { Histology; IC; IH; } \\
\text { RT-PCR } \\
\end{array}$ & $\begin{array}{l}\text { Reconstruction in } 66.7 \%(4 / 6) \text { of animals; } \\
\text { Corneal clarity: no data; } \\
\text { Severe neovascularization in one eye; } \\
\text { Mild superficial inflammation in one other }\end{array}$ \\
\hline $\begin{array}{c}\text { Lin et al. } 2013 \\
\qquad[51]\end{array}$ & $\begin{array}{l}\text { OFSCs; } \\
\text { Human }\end{array}$ & $\begin{array}{l}\text { Cultured in MesenPro medium; } \\
\text { Topical application of cells }(n=9) \text {, } \\
\text { Intra-limbal injection of cells }(n=3) \text {; } \\
\text { Control: Topical application of PBS }(n=6) \text {, } \\
\text { Injection of PBS }(n=3) \text {, no treatment }(n=3)\end{array}$ & $\begin{array}{l}\text { Mice; Filter paper } \\
\text { saturated with } 0.5 \mathrm{~N} \\
\mathrm{NaOH} \text { onto cornea }\end{array}$ & 1 week & $\begin{array}{l}\text { Digital camera; } \\
\text { Histology; IH; } \\
\text { IF; WB }\end{array}$ & $\begin{array}{l}\text { Reconstruction of corneal epithelium after } 1 \text { week; } \\
\text { Improved corneal clarity; } \\
\text { No neovascularization; } \\
\text { No complications }\end{array}$ \\
\hline
\end{tabular}

AM, amniotic membrane; CLCM, Confocal laser corneal microscopy; EM, electron microscopy; HFSCs, hair follicle-derived stem cells; IC, immunocytochemistry; IF, immunofluorescence; $\mathrm{IH}$, immunohistochemistry; IDPSCs, immature dental pulp stem cells; LSC, limbal stem cells; LSCD, limbal stem cell deficiency; MCB, mild chemical burn; OFSCs, orbital fat-derived stem cells; PBS, phosphate buffered saline; RT-PCR, reverse transcriptase polymerase chain reaction; SC, stem cell; SCB, severe chemical burn; UCSCs, umbilical cord stem cells. 
Table 5. Different culture and carrier biomaterials and methods used in cell-based therapies of LSCD, explored in animal models.

\begin{tabular}{ccc}
\hline Methods & Materials & References \\
\hline Transplantation & Carrier-free cell sheets & {$[36,41-44]$} \\
Transplantation & Amniotic membrane & {$[34,38,46,47,49,50,52,53]$} \\
Intravenous injection & - & {$[39]$} \\
Transplantation & Fibrin scaffold & {$[33,45,48]$} \\
Transplantation & Nanofiber scaffold & {$[40]$} \\
Injection under amniotic membrane & - & {$[37]$} \\
Topical application/Intra-limbal injection & - & {$[51]$} \\
\hline
\end{tabular}

\section{Substrates for Corneal Reconstruction}

To what extent biomechanical properties of the underlying substrate determine the success of ex vivo expansion of stem cells in treatment of LSCD is unknown. It is reasonable to assume that the optimal substrate will at least in some way resemble the limbal niche, in which limbal stem cells reside. The most common culture substrate for corneal reconstruction has so far been human AM. However, a number of alternative biological, biosynthetic, or synthetic substrates have been suggested as potential materials for ocular surface reconstruction (Table 6). The fundamental characteristics of an appropriate scaffold include cell attachment and cell proliferation both in culture and after transplantation, transparency, mechanical stability, and biocompatibility. In the studies on cell-based therapies for LSCD that have only been investigated in animal experiments, three substrates have so far been used: AM [34,38,46,47,49,50,52,53], nanofiber scaffold [40], and fibrin scaffold [33,45,48]. In addition, carrier-free methods [36,41-44], transplanting intact cell sheets without an underlying supportive membrane, injection of cells under transplanted AM [37], topical application of cells [51], intra-limbal injection of cells [51], and intravenous injection through an ear vein [39] have been applied (Table 5).

Amniotic membrane promotes cellular growth and exhibits anti-angiogenic and anti-inflammatory characteristics [54]. However, AM exhibits some significant disadvantages, including limited transparency and mechanical strength, poor standardization of preparation, risk for disease transmission, and biological variability (Table 7) [55]. There are extensive similarities between the basement membrane composition of AM and limbal niche, but AM lacks limbus-specific environmental factors, making it unsuitable as a surrogate niche for limbal stem cells [56]. In the studies on cell-based therapies of LSCD that have only been investigated in animal experiments, AM, with favorable results (Tables 1, 3, and 4), has been used as a substrate for culture and transplantation of bone marrow-derived mesenchymal stem cells (MSCs) [34,35,38], epidermal stem cells (SCs) [46,47], immature dental pulp stem cells (IDPSCs) [49,50], and umbilical cord stem cells (UCSCs) [52]. 
Table 6. Potential biomaterials and carriers for ocular surface reconstruction.

\begin{tabular}{ll}
\hline \multicolumn{1}{c}{ Biological/Biosynthetic } & \multicolumn{1}{c}{ Synthetic } \\
\hline Amniotic membrane [57] & Contact lenses [58] \\
Chemically cross-linked hyaluronic acid-based hydrogels [59] & Mebiol Gel (thermo-reversible polymer gel) [53] \\
Chitosan matrix/silver matrix/gold matrix [60] & Nanofiber scaffolds [40] \\
Collagen IV-coated plates [61] & Petrolatum gauze [24] \\
Collagen membranes [62] & Plastic [25] \\
Corneal stroma [63] & Poly(lactide-co-glycolide) electrospun scaffolds [64] \\
Fibrin [65] & Poly-8-caprolactone electrospun scaffolds [66] \\
Human keratoplasty lenticules [67] & \\
Laminin-coated compressed collagen gel [68] & \\
Matrigel (reconstituted basement membrane extract) [69] & \\
Plastic compressed collagen [70] & \\
Recombinant human cross-linked collagen scaffold [71] & \\
Silk fibroin [72] & \\
Silk fibroin mixed with polyethylene glycol [72] & \\
\hline
\end{tabular}

The list of possibilities is not complete.

As a substitution for natural extracellular matrix, investigators have attempted to produce synthetic nanofiber scaffolds, primarily using electrospinning [66], with the purpose of supporting cellular growth in corneal engineering. Nanofibers are three-dimensional (3D) and exhibit an enormous surface area. Polycaprolactone, which is a degradable polyester, has been found to have sufficient mechanical strength, high biocompatibility, low production costs, and ease of use (Table 7) [73]. Polycaprolactone has proved to be a suitable substrate for culture of corneal [66], limbal [66], and conjuntival cells [35]. Zajiceva et al. cultured bone marrow-derived MSCs on 3D nanofiber scaffolds fabricated from polyamide and transplanted the sheets onto the cornea of LSCD mice models [40]. The viability and morphology of cells grown on these nanofibers were comparable with those grown on plastic. Recently, a protocol for the use of nanofiber scaffolds for the growth of MSCs and limbal stem cells, and for their transplantation onto a damaged ocular surface in a mouse model, has been described, demonstrating the potential for nanofibers in clinical studies [74]. There are no studies, however, that have used nanofiber scaffolds for ocular surface reconstruction in humans.

Fibrin, a degradable natural substrate, has been used as a culture membrane in the treatment of LSCD in humans $[75,76]$. Fibrin substrates provide several advantages, such as relatively high mechanical strength, a high degree of transparency, and rapid bioadsorbence (Table 7) [54]. Fibrin, compared to, for example, collagen, has been shown to promote growth, survival, and an undifferentiated phenotype of cultured LEC [77]. The value of this membrane in ocular surface reconstruction has been further supported in LSCD rabbit models, using bone marrow-derived MSCs [33] and epidermal SCs [45], and in mice with hair follicle-derived stem cells (HFDSCs) [48].

Most of the cell-based therapeutic strategies entail the use of underlying substrate scaffolds. However, carrier-free methods, without a supportive membrane, have also been applied. Polymers that are responsive to temperature can detach adherent cells by reducing the temperature from $37{ }^{\circ} \mathrm{C}$ to $20^{\circ} \mathrm{C}$ [78]. Carrier-free techniques take advantage of adhesive properties of the basement membranes. It was demonstrated that the presence of $\beta_{1}$ integrin in the carrier-free group is important for the attachment of 
cell sheets to the ocular surface [79]. Promising results with carrier-free transplantation in animal studies are reported using bone marrow-derived MSCs in rabbits [36] and embryonic SCs in pigs [43] and mice $[41,42,44]$.

Table 7. Properties, advantages, and disadvantages of different carrier biomaterials and methods used in cell-based therapies of LSCD, explored in animal models.

\begin{tabular}{|c|c|c|c|c|c|}
\hline Carriers/Methods & Transparency & $\begin{array}{c}\text { Mechanical } \\
\text { Strength }\end{array}$ & Elasticity & Advantages & Disadvantages \\
\hline $\mathrm{AM}$ & + & ++ & +++ & $\begin{array}{l}\text { Stimulates cell growth, } \\
\text { anti-inflammation, } \\
\text { anti-angiogenesis, proper } \\
\text { elasticity }\end{array}$ & $\begin{array}{l}\text { Limited transparency, } \\
\text { variable quality, risk of } \\
\text { disease transmission, } \\
\text { limited mechanical } \\
\text { strength, poor } \\
\text { standardization }\end{array}$ \\
\hline $\begin{array}{c}\text { Carrier-free } \\
\text { method }\end{array}$ & N/A & N/A & $\mathrm{N} / \mathrm{A}$ & $\begin{array}{l}\text { Rapid adhesion, does not } \\
\text { require preparation and } \\
\text { standardization of } \\
\text { membranes, does not } \\
\text { require sutures }\end{array}$ & $\begin{array}{l}\text { Possibility for } \\
\text { detachment from } \\
\text { the ocular surface in } \\
\text { the early period } \\
\text { after surgery }\end{array}$ \\
\hline Fibrin gel & ++ & +++ & +++ & $\begin{array}{l}\text { Proper transparency, good } \\
\text { bioadsorbence, easy } \\
\text { manipulation, good } \\
\text { mechanical strength, } \\
\text { elasticity, degradable }\end{array}$ & $\begin{array}{l}\text { Possibility for immune } \\
\text { response, risk for } \\
\text { disease transmission }\end{array}$ \\
\hline Nanofiber & ++ & ++++ & ++ & $\begin{array}{l}\text { Good transparency, high } \\
\text { mechanical strength, } \\
\text { highly flexible, proper } \\
\text { biocompatibility, easy to } \\
\text { use, controlled shape and } \\
\text { pore size, low cost }\end{array}$ & $\begin{array}{l}\text { Limited elasticity, } \\
\text { high cost }\end{array}$ \\
\hline
\end{tabular}

N/A indicates not applicable.

\section{Cultured Bone Marrow-Derived Mesenchymal Stem Cells}

Mesenchymal stem cells have multi-lineage potential [80]. Previous studies have reported that bone marrow-derived MSCs have a beneficial effect on the survival, growth, and proliferation of various types of cells, such as cardiac progenitor cells [81], neural stem cells [82], neurons [83], and Schwann cells [84]. Studies have demonstrated that in vivo administration of MSCs decreases the incidence of graft-versus-host disease in humans and mice [85,86], inhibits the manifestation of autoimmune diseases [87], impairs septic complications [88], and considerably counteracts rejection of allogeneic corneal allografts [89]. After in vivo application of MSCs, these cells migrate into the damaged area, thus supporting tissue healing [90].

The role of bone marrow-derived MSCs has also been investigated in corneal tissue regeneration. To date, as many as eight animal studies have been performed using this cell source for corneal repair following induced LSCD (Table 1). Various substrates and methods have been applied to transplant 
cultured MSC cells to damaged cornea of mice, rats, and rabbits, including AM [34,35,38], nanofiber scaffold [40], fibrin scaffold [33], carrier-free sheets [36], injection under transplanted AM [37], and intravenous injection through an ear vein [39].

Overall, the results obtained from animal experiments show that bone marrow-derived MSCs have a favorable effect with regard to cell differentiation into a corneal epithelial phenotype, improved corneal clarity, and reduced vascularization (Table 1). In one mouse study, with the short follow-up time of two weeks, the authors reported that transplantation of bone marrow-derived MSCs on nanofiber scaffold carriers supported the epithelial healing and inhibited local inflammatory reactions [40]. The other studies, with follow-up times ranging from one to six months, reported that the reconstruction of corneal epithelium after transplantation of bone-marrow derived MSCs was achieved in 90.6\% (29/32) of the experimental rats $[34,35,38]$ and $100 \%(31 / 31)$ of the experimental rabbits [33,36,37,39]. In rats with induced LSCD, where cultured cells were transplanted on AM, the improved corneal clarity was achieved in $87.5 \%(28 / 32)$ of the transplanted animals, and the cornea was completely transparent in $78.6 \%(22 / 28)$ of the animals $[34,35,38]$. However, no studies reported that the cornea was completely transparent after transplantation in rabbit LSCD models [33,36,37,39]. In one of these studies where MSCs were transplanted on a fibrin carrier, the iris was partially clear in 30\% (3/10) and completely obscure in $70 \%(7 / 10)$ of the transplanted animals [33]. The studies in both rats and rabbits have also revealed that some neovascularization was observed in all transplanted eyes, with the best outcome being neovascularization limited to $2 \mathrm{~mm}$ central to the limbus 10 weeks after the transplantation [34].

It is speculated that the favorable effect of bone marrow-derived MSCs may be mediated by the intercellular signaling of epidermal growth factor (EGF) [91]. It has been suggested that EGF may be one of the most important mitogens of corneal epithelial cells [33,34]. Furthermore, bone marrow-derived MSCs induced to corneal lineage exhibited up-regulation of the putative limbal epithelial stem cell-specific genes p63 and $\beta_{1}$-integrin, and protein levels of p63 and CK3 were increased [38]. Other investigators have reported similar findings with the up-regulation of key putative stem cell markers [33,34,36,37]. This may be particularly important in the light of the recent finding by Rama et al. that the phenotype of cultured LEC is critical to ensure successful reconstruction of the ocular surface following LSCD [76]. The authors found that cell cultures in which p63-bright cells constituted more than $3 \%$ of the total number of cells were associated with successful transplantation in $78 \%$ of patients. In contrast, cultures in which p63-bright cells made up 3\% or less of the total number of cells, successful transplantation was only seen in $11 \%$ of patients. In conclusion, the investigations performed in animal experiments suggest that bone marrow-derived MSCs may serve as a possible stem cell source for corneal reconstruction in humans, however, neovascularization was a consistent feature following transplantation.

\section{Cultured Embryonic Stem Cells}

Embryonic SCs are widely accepted as a significant cell source in tissue regeneration due to their great plasticity. A number of cell types have been induced from embryonic SCs in vitro, e.g., lung alveolar epithelial cells [92] and epithelial cells of the thymus [93]. It has also been demonstrated that embryonic SCs are capable of differentiating into corneal epithelial-like cells [94,95]. There are hitherto four studies that have investigated the potential of embryonic SCs for regeneration of the cornea in animal LSCD models (Table 2). In these studies, embryonic SCs were either cultured on collagen 
IV [41-43] or gelatin coated plates [44]. After culture, the carrier-free cell sheets were transplanted onto the corneas of mice $[41,42,44]$ and pigs [43] (Table 2).

Following transplantation of cultured embryonic SCs onto corneas of LSCD animal models, re-epithelialization of the corneal surface with monolayer [41] and multilayer [42-44] epithelial-like cells was observed. The restored epithelium exhibited high levels of expression of CD44 and E-cadherin, which are important in corneal epithelial wound healing [41,42,44]. Furthermore, it has been demonstrated that embryonic SCs induced into epithelial-like cells expressed the basal limbal epithelial marker p63 [42,43] and the mature corneal epithelial marker CK12 [41-44].

Disadvantages of using embryonic SCs include difficulty of access, ethical concerns, high costs, immunogenicity, and risk of tumor formation [96]. None of the studies using embryonic SCs in animals have reported the degree of success in terms of number of animals with corneal reconstruction, or the effect on corneal transparency and neovascularization. Moreover, the follow-up time is very short (from one day to five weeks). Taken together, more studies with longer follow-up times, which also inform on the degree of success, are warranted prior to clinical trials.

\section{Cultured Epidermal Stem Cells}

Epidermal SCs have the remarkable ability to differentiate into other types of tissues [97]. Three studies have so far demonstrated the potential of epidermal SCs to regenerate the corneal surface following LSCD (Table 3). Two of the studies used AM for the culture and transplantation of epidermal SCs onto the cornea of goats [46,47], whereas the other used fibrin scaffold in rabbits [45]. These studies demonstrated that culture and transplantation of epidermal SCs onto damaged cornea successfully restored the corneal epithelium in 100\% (22/22) of the animals. Moreover, the cornea became completely transparent with only mild neovascularization [45-47]. In one study, the corneal surface was intact with normal transparency for over three months [45]. In a study by Yang and colleagues, with a follow-up time to 30 months, the cornea was clear in three or four quadrants in $80 \%(8 / 10)$ of animals [46]. In a third study, with a follow-up time to 24 months, $71.4 \%(5 / 7)$ of the eyes of the treated animals had two or three quadrants of clear cornea [47]. Corneal perforation during the operation was reported in one animal [47]. No other complications were noted in any of the animals.

Following transplantation of the epidermal SCs onto the cornea of goats, the epidermal markers CK1/10 were down-regulated in the corneal stroma at 12 months, whereas the expression of the CK3, CK12, and PAX6 was up-regulated in the reconstructed epithelium [46]. The authors suggested that a possible mechanism of epidermal SCs in reconstruction of the damaged corneal epithelium involves the down-regulation of CK1/10 and up-regulation of PAX6. The PAX6 gene is involved in controlling eye formation during embryonic development $[45,98,99]$, and recently the transduction of PAX6 in skin epithelial stem cells has been demonstrated to be adequate to transform epidermal SCs to limbal stem cell-like cells [45].

In conclusion, the results obtained with epidermal SCs in animal studies are very promising, with a high degree of success following transplantation in many animals, even with a follow-up period of 2.5 years $[46,47]$. Since epidermal SCs are also exceptionally easy to access, they may prove to be an excellent cell type for treating LSCD in humans. 


\section{Cultured Hair Follicle-Derived Stem Cells}

The hair follicle harbors mesenchymal stem cells in the dermal papilla and connective tissue sheath that have large plasticity and can differentiate - given appropriate conditions in vitro and in vivo - into several cell lineages. These include chondrogenic, osteogenic, adipogenic, myogenic, neurogenic, and hematopoietic cell lineages [100-102]. In addition, the hair follicle comprises stem cells of epithelial origin, residing in the bulge region of the outer root sheath. The cells possess the ability to differentiate into hair follicles and sebaceous glands under physiological conditions. Following injury, however, these stem cells differentiated into epidermis [103-105].

By means of conditioned media harvested from corneal and limbal stromal fibroblasts, Meyer-Blazejewska et al. found that hair follicle-derived stem cells (HFSCs) were able to be reprogrammed in vitro into cells with a corneal epithelial phenotype [106]. In a follow-up study, the same research group performed in vivo experiments using a transgenic mouse model that allows HFSCs to change color upon differentiation to corneal epithelial cells, in which CK12 is expressed [48]. Hair follicle-derived stem cells were cultured on fibrin scaffolds and transplanted onto the cornea of mice with induced LSCD. The achieved results were promising, with cell differentiation into a corneal epithelial phenotype and suppression of vascularization and conjunctival ingrowth with reconstruction of the ocular surface in $87.5 \%$ (7/8) of the transplanted animals two weeks following transplantation.

Due to promising results in an animal study comprising as many as 31 mice and extremely easy access, HFSCs clearly warrant further investigations.

\section{Cultured Immature Dental Pulp Stem Cells}

Human immature dental pulp cells (IDPSCs) are capable of differentiation into a multitude of cell types, including neurons, smooth and skeletal muscle, cartilage, and bone [107]. There are two animal studies using human IDPSCs to treat LSCD in which the cells were cultured on AM and transplanted onto the damaged cornea of rabbits [49,50]. Human immature dental pulp cells expressed markers in common with LEC/corneal cells, such as ABCG2, $\beta_{1}$-integrin, p63, and CK3/12 [50]. In 2009, Monteiro et al. [50] demonstrated that transplantation of IDPSCs resulted in reconstruction of the ocular surface in $100 \%(5 / 5)$ of experimental animals. The authors also reported gradual improvement in corneal transparency during a follow-up time of three months [50]. One year later, Gomes and colleagues showed that rabbit eyes after transplantation of IDPSCs exhibited well-organized corneal epithelium and improved corneal transparency in 100\% (5/5) of animals with mild chemical burn damage, while control corneas developed total conjunctivalization and opacification [49]. In the animals with severe chemical burns, $75 \%$ (3/4) of transplanted eyes showed less organized and loose corneal epithelium and inflammatory cells within the superficial and stromal layers. Furthermore, one animal exhibited a thin corneal epithelium and superficial neovascularization [49].

Overall, these two studies using IDPSC have shown that the transplantation of tissue engineered IDPSC sheets could successfully restore the ocular surface in animal models of LSCD. Human IDPSC are relatively easy to access from the dental pulp; however, the need for extraction of the tooth is a clear disadvantage with this technology. 


\section{Cultured Umbilical Cord Stem Cells}

There is only one study on the potential use of umbilical cord stem cells (UCSCs) to reverse LSCD in animals [52]. The UCSCs were cultured on AM and then transplanted onto the cornea of a LSCD rabbit model, resulting in regeneration of a clear corneal epithelium with a smooth surface and minimal corneal neovascularization in $66.7 \%(4 / 6)$ of the animals. Mild superficial inflammation was reported in one eye, whereas severe neovascularization was observed in the other. Furthermore, it was demonstrated that this new corneal smooth surface exhibited expression of normal corneal-specific markers CK3 and CK12, but not CK4 or CK1/10. Compared to embryonic SCs, umbilical cord stem cells have the advantage of being less immunogenic [108], non-tumorigenic [108], and ethically acceptable [52]. Compared to hair follicles and epidermal cells, the disadvantages of UCSCs include more complicated accessibility and allogeneic transplantation.

\section{Cultured Orbital Fat-Derived Stem Cells}

Multipotent stem cells have recently been successfully isolated and purified from human orbital fat tissue [109]. It has been demonstrated that the growth kinetics of orbital fat-derived stem cells (OFSCs) resemble those of bone marrow-derived MSCs, and that they share several surface markers [110]. Low immunogenicity of OFSC transplantation has been demonstrated in a xenotransplant model [110]. Furthermore, OFSCs possess adipogenic, chondrogenic, and osteogenic differentiation capacity, and are capable of differentiating into corneal epithelial cells in vitro [109]. So far, there is only one study on the potential use of OFSCs to treat damaged ocular surfaces in mice [51]. The authors reported that the topical administration and intra-limbal injection of OFSCs resulted in the reconstruction of clear corneal epithelium one week after treatment. It is suggested that inflammatory inhibition and corneal epithelial differentiation by OFSCs are responsible for corneal wound healing in the first few days, and that corneal stroma engraftment of OFSCs at a late stage is associated with corneal transparency [51]. The possibility of a topical approach to deliver OFSCs to reconstruct the ocular surface is particularly promising as it represents a non-invasive method. So far, few other non-invasive strategies have been suggested for the treatment of LSCD, and currently include the use of amniotic membrane extract [111], limbal fibroblast conditioned medium [112], and autologous serum [113], "a tonic for the ailing epithelium" [114].

\section{Challenges and Future Perspectives}

Over the past 10 years, a number of stem cell sources have been suggested for the treatment of ocular surface disorders. The clinical decision as to the optimal approach to treat LSCD has become challenging due to a precipitous increase in treatment options coupled with an almost absence of comparative studies. Comparisons between animal experiments of cell-based therapies of LSCD are difficult due to the following factors: (a) various methods for inducing LSCD in animals, (b) assorted culture techniques, (c) various transplantation methods, (d) differences in postoperative treatment, (e) disparities in follow-up time, and (f) huge differences in the presentation of experimental data. Increased standardization of these parameters will simplify the comparisons between animal experiments involving different stem cell sources, thereby encouraging corneal regenerative medicine. 
Mechanisms through which cell-based therapies reconstruct the ocular surface are still elusive. The transplanted cells may substitute the progenitor/stem cells of the host for a period of time and/or revitalize the stem cells of the host, e.g., by secreting growth factors. There are several lines of evidence supporting the hypothesis that cultured cells transplanted onto the cornea primarily work by providing a favorable environment. The fact that LSCD can be successfully treated by a number of cell types implies that factors other than the choice of cell type may govern clinical success. The identification of factors secreted from cultured non-limbal epithelial cells that may be involved in the revitalization of limbal stem cells is an exciting future avenue for research.

It is likely that the phenotype of cultured non-limbal cells affects success following transplantation [76]. Studies on how various culture parameters affect the cell sheet, with particular emphasis on the phenotype, are warranted.

\section{Conclusions}

Animal experiments with epidermal SCs, HFSCs, IDPSCs, and bone marrow-derived MSCs have all shown promising results for the treatment of LSCD (Table 8). They represent an autologous source of cells in contrast to embryonic SCs and UCSCs. The long-term effects using embryonic SCs and UCSCs are unknown as none of the cell types have a follow-up time longer than five weeks. This contrasts sharply with the 2.5 year follow-up time for transplanted cultured epidermal SCs. Epidermal SCs and HFSCs both have the distinct benefit of exceptional ease of access. Coupled with promising results in many animals, these two types are particularly strong candidates for future clinical trials. Future research on these cells could include the development of a xenobiotic culture and storage [115-120] system that can keep the cells in a relatively undifferentiated state [76], while maintaining sufficient strength to be suitable for transplantation. Such a system would increase the safety [121], flexibility [122], global impact [123], and, most likely, the clinical results of the transplants [76].

Table 8. Overall success in ocular surface reconstruction using different stem cell sources.

\begin{tabular}{ccccccc}
\hline $\begin{array}{c}\text { Types of Stem } \\
\text { Cells }\end{array}$ & Success & $\begin{array}{c}\text { Complications } \\
\text { (Number of Animals) }\end{array}$ & $\begin{array}{c}\text { Ease of } \\
\text { Access }\end{array}$ & $\begin{array}{c}\text { Number of Animals } \\
\text { (Number of } \\
\text { Studies) }\end{array}$ & $\begin{array}{c}\text { Autologous } \\
\text { Source }\end{array}$ & $\begin{array}{c}\text { Ethical } \\
\text { Concerns }\end{array}$ \\
\hline $\begin{array}{c}\text { Bone Marrow- } \\
\text { Derived MSCs }\end{array}$ & +++ & - & ++ & $63(8)^{1}$ & Yes & No \\
Embryonic SCs & + & Mild immune reaction* & + & $25(4)^{2}$ & No & Yes \\
Epidermal SCs & ++++ & Perforation (1) & ++++ & $22(3)$ & Yes & No \\
HFSCs & +++ & - & ++++ & $31(1)$ & Yes & No \\
IDPSCs & +++ & - & ++ & $14(2)$ & Yes & No \\
OFSCs & ++ & - & ++ & $12(1)$ & Yes & No \\
UCSCs & ++ & Mild superficial & ++ & $6(1)$ & No & No \\
\hline
\end{tabular}

${ }^{1}$ number of animals not reported in two studies; ${ }^{2}$ number of animals not reported in one study; $*$ number of animals not reported; HFSCs, hair follicle-derived stem cells; MSCs, mesenchymal stem cells; SCs, stem cells; OFSCs, orbital fat-derived stem cells; UCSCs, umbilical cord stem cells; +: low degree; ++: moderate degree; +++: high degree; ++++: very high degree. 


\section{Acknowledgments}

Funding received from Department of Oral Biology, Faculty of Dentistry, University of Oslo and Department of Medical Biochemistry, Oslo University Hospital, Oslo, Norway.

\section{Conflicts of Interest}

The authors declare no conflict of interest.

\section{References}

1. Land, M.F.; Fernald, R.D. The evolution of eyes. Annu. Rev. Neurosci. 1992, 15, 1-29.

2. Beuerman, R.W.; Pedroza, L. Ultrastructure of the human cornea. Microsc. Res. Tech. 1996, 33, 320-335.

3. Robertson, D.M.; Ladage, P.M.; Yamamoto, N.; Jester, J.V.; Petroll, W.M.; Cavanagh, H.D. Bcl-2 and bax regulation of corneal homeostasis in genetically altered mice. Eye Contact Lens 2006, 32, 3-7.

4. Moller-Pedersen, T.; Li, H.F.; Petroll, W.M.; Cavanagh, H.D.; Jester, J.V. Confocal microscopic characterization of wound repair after photorefractive keratectomy. Invest. Ophthalmol. Vis. Sci. 1998, 39, 487-501.

5. Cavanagh, H.D.; Ladage, P.M.; Li, S.L.; Yamamoto, K.; Molai, M.; Ren, D.H.; Petroll, W.M.; Jester, J.V. Effects of daily and overnight wear of a novel hyper oxygen-transmissible soft contact lens on bacterial binding and corneal epithelium: A 13-month clinical trial. Ophthalmology 2002, 109, 1957-1969.

6. Sharma, A.; Coles, W.H. Kinetics of corneal epithelial maintenance and graft loss. A population balance model. Invest. Ophthalmol. Vis. Sci. 1989, 30, 1962-1971.

7. Utheim, T.P. Limbal epithelial cell therapy: Past, present, and future. Methods Mol. Biol. 2013, 1014, 3-43.

8. Nishida, T. Fundamentals, diagnosis and management. In Cornea, 2nd ed.; Krachmer, J.H., Mannis, M.J., Holland, E., Eds.; Elsevier: Philadelphia, PA, USA, 2005; pp. 3-26.

9. Cotsarelis, G.; Cheng, S.Z.; Dong, G.; Sun, T.T.; Lavker, R.M. Existence of slow-cycling limbal epithelial basal cells that can be preferentially stimulated to proliferate: Implications on epithelial stem cells. Cell 1989, 57, 201-209.

10. Davanger, M.; Evensen, A. Role of the pericorneal papillary structure in renewal of corneal epithelium. Nature 1971, 229, 560-561.

11. Zieske, J.D. Perpetuation of stem cells in the eye. Eye 1994, 8, 163-169.

12. Schermer, A.; Galvin, S.; Sun, T.T. Differentiation-related expression of a major $64 \mathrm{~K}$ corneal keratin in vivo and in culture suggests limbal location of corneal epithelial stem cells. J. Cell Biol. 1986, 103, 49-62.

13. Pellegrini, G.; Rama, P.; Mavilio, F.; De Luca, M. Epithelial stem cells in corneal regeneration and epidermal gene therapy. J. Pathol. 2009, 217, 217-228. 
14. Schwartz, G.; Holland, E.J. Cornea: Fundamentals, diagnosis and management. In Classification and Staging of Ocular Surface Disease, 2nd ed.; Krachmer, J.H., Mannis, M.J., Holland, E., Eds.; Elsevier: Philadelphia, PA, USA, 2005; pp. 1785-1797.

15. Vemuganti, G.K.; Sangwan, V.S. Interview: Affordability at the cutting edge: Stem cell therapy for ocular surface reconstruction. Regen. Med. 2010, 5, 337-340.

16. Schwab, I.R.; Isseroff, R.R. Bioengineered corneas-The promise and the challenge. N. Engl. J. Med. 2000, 343, 136-138.

17. Puangsricharern, V.; Tseng, S.C. Cytologic evidence of corneal diseases with limbal stem cell deficiency. Ophthalmology 1995, 102, 1476-1485.

18. Espana, E.M.; Grueterich, M.; Romano, A.C.; Touhami, A.; Tseng, S.C. Idiopathic limbal stem cell deficiency. Ophthalmology 2002, 109, 2004-2010.

19. Dua, H.S.; Joseph, A.; Shanmuganathan, V.A.; Jones, R.E. Stem cell differentiation and the effects of deficiency. Eye 2003, 17, 877-885.

20. Di Iorio, E.; Ferrari, S.; Fasolo, A.; Bohm, E.; Ponzin, D.; Barbaro, V. Techniques for culture and assessment of limbal stem cell grafts. Ocul. Surf. 2010, 8, 146-153.

21. Shortt, A.J.; Secker, G.A.; Rajan, M.S.; Meligonis, G.; Dart, J.K.; Tuft, S.J.; Daniels, J.T. Ex vivo expansion and transplantation of limbal epithelial stem cells. Ophthalmology 2008, 115, 1989-1997.

22. Rauz, S.; Saw, V.P. Serum eye drops, amniotic membrane and limbal epithelial stem cells - tools in the treatment of ocular surface disease. Cell Tissue Bank. 2010, 11, 13-27.

23. Kenyon, K.R.; Tseng, S.C. Limbal autograft transplantation for ocular surface disorders. Ophthalmology 1989, 96, 709-722.

24. Pellegrini, G.; Traverso, C.E.; Franzi, A.T.; Zingirian, M.; Cancedda, R.; De Luca, M. Long-term restoration of damaged corneal surfaces with autologous cultivated corneal epithelium. Lancet 1997, 349, 990-993.

25. Daya, S.M.; Watson, A.; Sharpe, J.R.; Giledi, O.; Rowe, A.; Martin, R.; James, S.E. Outcomes and DNA analysis of ex vivo expanded stem cell allograft for ocular surface reconstruction. Ophthalmology 2005, 112, 470-477.

26. Hayashi, R.; Ishikawa, Y.; Ito, M.; Kageyama, T.; Takashiba, K.; Fujioka, T.; Tsujikawa, M.; Miyoshi, H.; Yamato, M.; Nakamura, Y.; et al. Generation of corneal epithelial cells from induced pluripotent stem cells derived from human dermal fibroblast and corneal limbal epithelium. PloS ONE 2012, 7, doi:10.1371/journal.pone.0045435.

27. Sareen, D.; Saghizadeh, M.; Ornelas, L.; Winkler, M.A.; Narwani, K.; Sahabian, A.; Funari, V.A.; Tang, J.; Spurka, L.; Punj, V.; et al. Differentiation of human limbal-derived induced pluripotent stem cells into limbal-like epithelium. Stem Cells Transl. Med. 2014, 3, 1002-1012.

28. Niethammer, D.; Kummerle-Deschner, J.; Dannecker, G.E. Side-effects of long-term immunosuppression versus morbidity in autologous stem cell rescue: Striking the balance. Rheumatology 1999, 38, 747-750.

29. Utheim, T.P. Concise review: Transplantation of cultured oral mucosal epithelial cells for treating limbal stem cell deficiency-current status and future perspectives. Stem Cells 2015, 33, 1685-1695. 
30. Di Girolamo, N.; Bosch, M.; Zamora, K.; Coroneo, M.T.; Wakefield, D.; Watson, S.L. A contact lens-based technique for expansion and transplantation of autologous epithelial progenitors for ocular surface reconstruction. Transplantation 2009, 87, 1571-1578.

31. Chun, Y.S.; Park, I.K.; Kim, J.C. Technique for autologous nasal mucosa transplantation in severe ocular surface disease. Eur. J. Ophthalmol. 2011, 21, 545-551.

32. Kim, J.H.; Chun, Y.S.; Lee, S.H.; Mun, S.K.; Jung, H.S.; Lee, S.H.; Son, Y.; Kim, J.C. Ocular surface reconstruction with autologous nasal mucosa in cicatricial ocular surface disease. Am. J. Ophthalmol. 2010, 149, 45-53.

33. Gu, S.; Xing, C.; Han, J.; Tso, M.O.; Hong, J. Differentiation of rabbit bone marrow mesenchymal stem cells into corneal epithelial cells in vivo and ex vivo. Molecular vision 2009, 15, 99-107.

34. Jiang, T.S.; Cai, L.; Ji, W.Y.; Hui, Y.N.; Wang, Y.S.; Hu, D.; Zhu, J. Reconstruction of the corneal epithelium with induced marrow mesenchymal stem cells in rats. Mol. Vis. 2010, 16, 1304-1316.

35. Ma, Y.; Xu, Y.; Xiao, Z.; Yang, W.; Zhang, C.; Song, E.; Du, Y.; Li, L. Reconstruction of chemically burned rat corneal surface by bone marrow-derived human mesenchymal stem cells. Stem Cells 2006, 24, 315-321.

36. Omoto, M.; Miyashita, H.; Shimmura, S.; Higa, K.; Kawakita, T.; Yoshida, S.; McGrogan, M.; Shimazaki, J.; Tsubota, K. The use of human mesenchymal stem cell-derived feeder cells for the cultivation of transplantable epithelial sheets. Invest. Ophthalmol. Vis. Sci. 2009, 50, 2109-2115.

37. Reinshagen, H.; Auw-Haedrich, C.; Sorg, R.V.; Boehringer, D.; Eberwein, P.; Schwartzkopff, J.; Sundmacher, R.; Reinhard, T. Corneal surface reconstruction using adult mesenchymal stem cells in experimental limbal stem cell deficiency in rabbits. Acta Ophthalmol. 2011, 89, 741-748.

38. Rohaina, C.M.; Then, K.Y.; Ng, A.M.; Wan Abdul Halim, W.H.; Zahidin, A.Z.; Saim, A.; Idrus, R.B. Reconstruction of limbal stem cell deficient corneal surface with induced human bone marrow mesenchymal stem cells on amniotic membrane. Transl. Res. 2014, 163, 200-210.

39. Ye, J.; Yao, K.; Kim, J.C. Mesenchymal stem cell transplantation in a rabbit corneal alkali burn model: Engraftment and involvement in wound healing. Eye 2006, 20, 482-490.

40. Zajicova, A.; Pokorna, K.; Lencova, A.; Krulova, M.; Svobodova, E.; Kubinova, S.; Sykova, E.; Pradny, M.; Michalek, J.; Svobodova, J.; et al. Treatment of ocular surface injuries by limbal and mesenchymal stem cells growing on nanofiber scaffolds. Cell Transpl. 2010, 19, 1281-1290.

41. Homma, R.; Yoshikawa, H.; Takeno, M.; Kurokawa, M.S.; Masuda, C.; Takada, E.; Tsubota, K.; Ueno, S.; Suzuki, N. Induction of epithelial progenitors in vitro from mouse embryonic stem cells and application for reconstruction of damaged cornea in mice. Invest. Ophthalmol. Vis. Sci. 2004, 45, 4320-4326.

42. Kumagai, Y.; Kurokawa, M.S.; Ueno, H.; Kayama, M.; Tsubota, K.; Nakatsuji, N.; Kondo, Y.; Ueno, S.; Suzuki, N. Induction of corneal epithelium-like cells from cynomolgus monkey embryonic stem cells and their experimental transplantation to damaged cornea. Cornea 2010, 29, 432-438.

43. Notara, M.; Hernandez, D.; Mason, C.; Daniels, J.T. Characterization of the phenotype and functionality of corneal epithelial cells derived from mouse embryonic stem cells. Regen. Med. 2012, 7, 167-178.

44. Ueno, H.; Kurokawa, M.S.; Kayama, M.; Homma, R.; Kumagai, Y.; Masuda, C.; Takada, E.; Tsubota, K.; Ueno, S.; Suzuki, N. Experimental transplantation of corneal epithelium-like cells induced by PAX6 gene transfection of mouse embryonic stem cells. Cornea 2007, 26, 1220-1227. 
45. Ouyang, H.; Xue, Y.; Lin, Y.; Zhang, X.; Xi, L.; Patel, S.; Cai, H.; Luo, J.; Zhang, M.; Zhang, M.; et al. WNT7a and PAX6 define corneal epithelium homeostasis and pathogenesis. Nature 2014, 511, 358-361.

46. Yang, X.; Moldovan, N.I.; Zhao, Q.; Mi, S.; Zhou, Z.; Chen, D.; Gao, Z.; Tong, D.; Dou, Z. Reconstruction of damaged cornea by autologous transplantation of epidermal adult stem cells. Mol. Vis. 2008, 14, 1064-1070.

47. Yang, X.; Qu, L.; Wang, X.; Zhao, M.; Li, W.; Hua, J.; Shi, M.; Moldovan, N.; Wang, H.; Dou, Z. Plasticity of epidermal adult stem cells derived from adult goat ear skin. Mol. Reprod. Dev. 2007, 74, 386-396.

48. Meyer-Blazejewska, E.A.; Call, M.K.; Yamanaka, O.; Liu, H.; Schlotzer-Schrehardt, U.; Kruse, F.E.; Kao, W.W. From hair to cornea: Toward the therapeutic use of hair follicle-derived stem cells in the treatment of limbal stem cell deficiency. Stem Cells 2011, 29, 57-66.

49. Gomes, J.A.; Geraldes Monteiro, B.; Melo, G.B.; Smith, R.L.; Cavenaghi Pereira da Silva, M.; Lizier, N.F.; Kerkis, A.; Cerruti, H.; Kerkis, I. Corneal reconstruction with tissue-engineered cell sheets composed of human immature dental pulp stem cells. Invest. Ophthalmol. Vis. Sci. 2010, 51, 1408-1414.

50. Monteiro, B.G.; Serafim, R.C.; Melo, G.B.; Silva, M.C.; Lizier, N.F.; Maranduba, C.M.; Smith, R.L.; Kerkis, A.; Cerruti, H.; Gomes, J.A.; et al. Human immature dental pulp stem cells share key characteristic features with limbal stem cells. Cell Prolif. 2009, 42, 587-594.

51. Lin, K.J.; Loi, M.X.; Lien, G.S.; Cheng, C.F.; Pao, H.Y.; Chang, Y.C.; Ji, A.T.; Ho, J.H. Topical administration of orbital fat-derived stem cells promotes corneal tissue regeneration. Stem Cell Res. Ther. 2013, 4, doi:10.1186/scrt223.

52. Reza, H.M.; Ng, B.Y.; Gimeno, F.L.; Phan, T.T.; Ang, L.P. Umbilical cord lining stem cells as a novel and promising source for ocular surface regeneration. Stem Cell Rev. 2011, 7, 935-947.

53. Sudha, B.; Madhavan, H.N.; Sitalakshmi, G.; Malathi, J.; Krishnakumar, S.; Mori, Y.; Yoshioka, H.; Abraham, S. Cultivation of human corneal limbal stem cells in mebiol gel-A thermo-reversible gelation polymer. Indian J. Med. Res. 2006, 124, 655-664.

54. Feng, Y.; Borrelli, M.; Reichl, S.; Schrader, S.; Geerling, G. Review of alternative carrier materials for ocular surface reconstruction. Curr. Eye Res. 2014, 39, 541-552.

55. Levis, H.; Daniels, J.T. New technologies in limbal epithelial stem cell transplantation. Curr. Opin. Biotechnol. 2009, 20, 593-597.

56. Dietrich-Ntoukas, T.; Hofmann-Rummelt, C.; Kruse, F.E.; Schlotzer-Schrehardt, U. Comparative analysis of the basement membrane composition of the human limbus epithelium and amniotic membrane epithelium. Cornea 2012, 31, 564-569.

57. Meller, D.; Tseng, S.C. Conjunctival epithelial cell differentiation on amniotic membrane. Investig. Ophthalmol. Vis. Sci. 1999, 40, 878-886.

58. Di Girolamo, N.; Chui, J.; Wakefield, D.; Coroneo, M.T. Cultured human ocular surface epithelium on therapeutic contact lenses. Br. J. Ophthalmol. 2007, 91, 459-464.

59. Fiorica, C.; Senior, R.A.; Pitarresi, G.; Palumbo, F.S.; Giammona, G.; Deshpande, P.; MacNeil, S. Biocompatible hydrogels based on hyaluronic acid cross-linked with a polyaspartamide derivative as delivery systems for epithelial limbal cells. Int. J. Pharm. 2011, 414, 104-111. 
60. Sudha, B.; Jasty, S.; Krishnan, S.; Krishnakumar, S. Signal transduction pathway involved in the ex vivo expansion of limbal epithelial cells cultured on various substrates. Indian J. Med. Res. 2009, 129, 382-389.

61. Li, D.Q.; Chen, Z.; Song, X.J.; de Paiva, C.S.; Kim, H.S.; Pflugfelder, S.C. Partial enrichment of a population of human limbal epithelial cells with putative stem cell properties based on collagen type IV adhesiveness. Exp. Eye Res. 2005, 80, 581-590.

62. Kito, K.; Kagami, H.; Kobayashi, C.; Ueda, M.; Terasaki, H. Effects of cryopreservation on histology and viability of cultured corneal epithelial cell sheets in rabbit. Cornea 2005, 24, 735-741.

63. Friend, J.; Kinoshita, S.; Thoft, R.A.; Eliason, J.A. Corneal epithelial cell cultures on stromal carriers. Investig. Ophthalmol. Vis. Sci. 1982, 23, 41-49.

64. Deshpande, P.; McKean, R.; Blackwood, K.A.; Senior, R.A.; Ogunbanjo, A.; Ryan, A.J.; MacNeil, S. Using poly(lactide-co-glycolide) electrospun scaffolds to deliver cultured epithelial cells to the cornea. Regen Med. 2010, 5, 395-401.

65. Talbot, M.; Carrier, P.; Giasson, C.J.; Deschambeault, A.; Guerin, S.L.; Auger, F.A.; Bazin, R.; Germain, L. Autologous transplantation of rabbit limbal epithelia cultured on fibrin gels for ocular surface reconstruction. Mol. Vis. 2006, 12, 65-75.

66. Sharma, S.; Mohanty, S.; Gupta, D.; Jassal, M.; Agrawal, A.K.; Tandon, R. Cellular response of limbal epithelial cells on electrospun poly-epsilon-caprolactone nanofibrous scaffolds for ocular surface bioengineering: A preliminary in vitro study. Mol. Vis. 2011, 17, 2898-2910.

67. Barbaro, V.; Ferrari, S.; Fasolo, A.; Ponzin, D.; Di Iorio, E. Reconstruction of a human hemicornea through natural scaffolds compatible with the growth of corneal epithelial stem cells and stromal keratocytes. Mol. Vis. 2009, 15, 2084-2093.

68. Mi, S.; Chen, B.; Wright, B.; Connon, C.J. Ex vivo construction of an artificial ocular surface by combination of corneal limbal epithelial cells and a compressed collagen scaffold containing keratocytes. Tissue Eng. Part A 2010, 16, 2091-2100.

69. Ahmadiankia, N.; Ebrahimi, M.; Hosseini, A.; Baharvand, H. Effects of different extracellular matrices and co-cultures on human limbal stem cell expansion in vitro. Cell Biol. Int. 2009, 33, 978-987.

70. Levis, H.J.; Brown, R.A.; Daniels, J.T. Plastic compressed collagen as a biomimetic substrate for human limbal epithelial cell culture. Biomaterials 2010, 31, 7726-7737.

71. Dravida, S.; Gaddipati, S.; Griffith, M.; Merrett, K.; Lakshmi Madhira, S.; Sangwan, V.S.; Vemuganti, G.K. A biomimetic scaffold for culturing limbal stem cells: A promising alternative for clinical transplantation. J. Tissue Eng. Regen Med. 2008, 2, 263-271.

72. Higa, K.; Takeshima, N.; Moro, F.; Kawakita, T.; Kawashima, M.; Demura, M.; Shimazaki, J.; Asakura, T.; Tsubota, K.; Shimmura, S. Porous silk fibroin film ass a transparent carrier for cultivated corneal epithelial sheets. J. Biomater Sci. Polym. Ed. 2010, 22, doi:10.1163/092050610 X538218

73. Redenti, S.; Tao, S.; Yang, J.; Gu, P.; Klassen, H.; Saigal, S.; Desai, T.; Young, M.J. Retinal tissue engineering using mouse retinal progenitor cells and a novel biodegradable, thin-film poly(e-caprolactone) nanowire scaffold. J. Ocul. Biol. Dis. Infor. 2008, 1, 19-29.

74. Holan, V.; Javorkova, E.; Trosan, P. The growth and delivery of mesenchymal and limbal stem cells using copolymer polyamide 6/12 nanofiber scaffolds. Methods Mol. Biol. 2013, 1014, 187-199. 
75. Rama, P.; Bonini, S.; Lambiase, A.; Golisano, O.; Paterna, P.; De Luca, M.; Pellegrini, G. Autologous fibrin-cultured limbal stem cells permanently restore the corneal surface of patients with total limbal stem cell deficiency. Transplantation 2001, 72, 1478-1485.

76. Rama, P.; Matuska, S.; Paganoni, G.; Spinelli, A.; De Luca, M.; Pellegrini, G. Limbal stem-cell therapy and long-term corneal regeneration. N. Engl. J. Med. 2010, 363, 147-155.

77. Forni, M.F.; Loureiro, R.R.; Cristovam, P.C.; Bonatti, J.A.; Sogayar, M.C.; Gomes, J.A. Comparison between different biomaterial scaffolds for limbal-derived stem cells growth and enrichment. Curr. Eye Res. 2013, 38, 27-34.

78. Nishida, K.; Yamato, M.; Hayashida, Y.; Watanabe, K.; Maeda, N.; Watanabe, H.; Yamamoto, K.; Nagai, S.; Kikuchi, A.; Tano, Y.; et al. Functional bioengineered corneal epithelial sheet grafts from corneal stem cells expanded ex vivo on a temperature-responsive cell culture surface. Transplantation 2004, 77, 379-385.

79. Higa, K.; Shimmura, S.; Kato, N.; Kawakita, T.; Miyashita, H.; Itabashi, Y.; Fukuda, K.; Shimazaki, J.; Tsubota, K. Proliferation and differentiation of transplantable rabbit epithelial sheets engineered with or without an amniotic membrane carrier. Invest. Ophthalmol. Vis. Sci. 2007, 48, 597-604.

80. Pittenger, M.F.; Mackay, A.M.; Beck, S.C.; Jaiswal, R.K.; Douglas, R.; Mosca, J.D.; Moorman, M.A.; Simonetti, D.W.; Craig, S.; Marshak, D.R. Multilineage potential of adult human mesenchymal stem cells. Science 1999, 284, 143-147.

81. Nakanishi, C.; Yamagishi, M.; Yamahara, K.; Hagino, I.; Mori, H.; Sawa, Y.; Yagihara, T.; Kitamura, S.; Nagaya, N. Activation of cardiac progenitor cells through paracrine effects of mesenchymal stem cells. Biochem. Biophys. Res. Commun. 2008, 374, 11-16.

82. Yoo, S.W.; Kim, S.S.; Lee, S.Y.; Lee, H.S.; Kim, H.S.; Lee, Y.D.; Suh-Kim, H. Mesenchymal stem cells promote proliferation of endogenous neural stem cells and survival of newborn cells in a rat stroke model. Exp. Mol. Med. 2008, 40, 387-397.

83. Deng, Y.B.; Ye, W.B.; Hu, Z.Z.; Yan, Y.; Wang, Y.; Takon, B.F.; Zhou, G.Q.; Zhou, Y.F. Intravenously administered BMSCs reduce neuronal apoptosis and promote neuronal proliferation through the release of VEGF after stroke in rats. Neurol. Res. 2010, 32, 148-156.

84. Wang, J.; Ding, F.; Gu, Y.; Liu, J.; Gu, X. Bone marrow mesenchymal stem cells promote cell proliferation and neurotrophic function of Schwann cells in vitro and in vivo. Brain Res. 2009, 1262, 7-15.

85. Lazarus, H.M.; Koc, O.N.; Devine, S.M.; Curtin, P.; Maziarz, R.T.; Holland, H.K.; Shpall, E.J.; McCarthy, P.; Atkinson, K.; Cooper, B.W.; et al. Cotransplantation of HLA-identical sibling culture-expanded mesenchymal stem cells and hematopoietic stem cells in hematologic malignancy patients. Biol. Blood Marrow Transpl. 2005, 11, 389-398.

86. Le Blanc, K.; Rasmusson, I.; Sundberg, B.; Gotherstrom, C.; Hassan, M.; Uzunel, M.; Ringden, O. Treatment of severe acute graft-versus-host disease with third party haploidentical mesenchymal stem cells. Lancet 2004, 363, 1439-1441.

87. Zappia, E.; Casazza, S.; Pedemonte, E.; Benvenuto, F.; Bonanni, I.; Gerdoni, E.; Giunti, D.; Ceravolo, A.; Cazzanti, F.; Frassoni, F.; et al. Mesenchymal stem cells ameliorate experimental autoimmune encephalomyelitis inducing T-cell anergy. Blood 2005, 106, 1755-1761. 
88. Wu, Y.; Chen, L.; Scott, P.G.; Tredget, E.E. Mesenchymal stem cells enhance wound healing through differentiation and angiogenesis. Stem Cells 2007, 25, 2648-2659.

89. Jia, Z.; Jiao, C.; Zhao, S.; Li, X.; Ren, X.; Zhang, L.; Han, Z.C.; Zhang, X. Immunomodulatory effects of mesenchymal stem cells in a rat corneal allograft rejection model. Exp. Eye Res. 2012, 102, 44-49.

90. Sasaki, M.; Abe, R.; Fujita, Y.; Ando, S.; Inokuma, D.; Shimizu, H. Mesenchymal stem cells are recruited into wounded skin and contribute to wound repair by transdifferentiation into multiple skin cell type. J. Immunol. 2008, 180, 2581-2587.

91. Hu, N.; Zhang, Y.Y.; Gu, H.W.; Guan, H.J. Effects of bone marrow mesenchymal stem cells on cell proliferation and growth factor expression of limbal epithelial cells in vitro. Ophthalmic Res. 2012, 48, 82-88.

92. Ali, N.N.; Edgar, A.J.; Samadikuchaksaraei, A.; Timson, C.M.; Romanska, H.M.; Polak, J.M.; Bishop, A.E. Derivation of type II alveolar epithelial cells from murine embryonic stem cells. Tissue Eng. 2002, 8, 541-550.

93. Rodewald, H.R.; Paul, S.; Haller, C.; Bluethmann, H.; Blum, C. Thymus medulla consisting of epithelial islets each derived from a single progenitor. Nature 2001, 414, 763-768.

94. Ahmad, S.; Stewart, R.; Yung, S.; Kolli, S.; Armstrong, L.; Stojkovic, M.; Figueiredo, F.; Lako, M. Differentiation of human embryonic stem cells into corneal epithelial-like cells by in vitro replication of the corneal epithelial stem cell niche. Stem Cells 2007, 25, 1145-1155.

95. Brzeszczynska, J.; Samuel, K.; Greenhough, S.; Ramaesh, K.; Dhillon, B.; Hay, D.C.; Ross, J.A. Differentiation and molecular profiling of human embryonic stem cell-derived corneal epithelial cells. Int. J. Mol. Med. 2014, 33, 1597-1606.

96. Cui, L.; Guan, Y.; Qu, Z.; Zhang, J.; Liao, B.; Ma, B.; Qian, J.; Li, D.; Li, W.; Xu, G.T.; et al. WNT signaling determines tumorigenicity and function of ESC-derived retinal progenitors. J. Clin. Investg. 2013, 123, 1647-1661.

97. Liang, L.; Bickenbach, J.R. Somatic epidermal stem cells can produce multiple cell lineages during development. Stem Cells 2002, 20, 21-31.

98. Tsonis, P.A.; Fuentes, E.J. Focus on molecules: PAX-6, the eye master. Exp. Eye Res. 2006, 83, 233-234.

99. Treisman, J.E. How to make an eye. Development 2004, 131, 3823-3827.

100. Jahoda, C.A.; Whitehouse, J.; Reynolds, A.J.; Hole, N. Hair follicle dermal cells differentiate into adipogenic and osteogenic lineages. Exp. Dermatol. 2003, 12, 849-859.

101. Lako, M.; Armstrong, L.; Cairns, P.M.; Harris, S.; Hole, N.; Jahoda, C.A. Hair follicle dermal cells repopulate the mouse haematopoietic system. J. Cell Sci. 2002, 115, 3967-3974.

102. Richardson, G.D.; Arnott, E.C.; Whitehouse, C.J.; Lawrence, C.M.; Reynolds, A.J.; Hole, N.; Jahoda, C.A. Plasticity of rodent and human hair follicle dermal cells: Implications for cell therapy and tissue engineering. J. Investig. Dermatol. Symp. Proc. 2005, 10, 180-183.

103. Cotsarelis, G. Epithelial stem cells: A folliculocentric view. J. Investig. Dermatol. 2006, 126, 1459-1468.

104. Cotsarelis, G.; Sun, T.T.; Lavker, R.M. Label-retaining cells reside in the bulge area of pilosebaceous unit: Implications for follicular stem cells, hair cycle, and skin carcinogenesis. Cell 1990, 61, 1329-1337. 
105. Taylor, G.; Lehrer, M.S.; Jensen, P.J.; Sun, T.T.; Lavker, R.M. Involvement of follicular stem cells in forming not only the follicle but also the epidermis. Cell 2000, 102, 451-461.

106. Blazejewska, E.A.; Schlotzer-Schrehardt, U.; Zenkel, M.; Bachmann, B.; Chankiewitz, E.; Jacobi, C.; Kruse, F.E. Corneal limbal microenvironment can induce transdifferentiation of hair follicle stem cells into corneal epithelial-like cells. Stem Cells 2009, 27, 642-652.

107. Kerkis, I.; Kerkis, A.; Dozortsev, D.; Stukart-Parsons, G.C.; Gomes Massironi, S.M.; Pereira, L.V.; Caplan, A.I.; Cerruti, H.F. Isolation and characterization of a population of immature dental pulp stem cells expressing OCT-4 and other embryonic stem cell markers. Cells Tissues Organs 2006, 184, 105-116.

108. Xiong, N.; Cao, X.; Zhang, Z.; Huang, J.; Chen, C.; Zhang, Z.; Jia, M.; Xiong, J.; Liang, Z.; Sun, S.; et al. Long-term efficacy and safety of human umbilical cord mesenchymal stromal cells in rotenone-induced hemiparkinsonian rats. Biol. Blood Marrow Transpl. 2010, 16, 1519-1529.

109. Ho, J.H.; Ma, W.H.; Tseng, T.C.; Chen, Y.F.; Chen, M.H.; Lee, O.K. Isolation and characterization of multi-potent stem cells from human orbital fat tissues. Tissue Eng. Part A 2011, 17, 255-266.

110. Chien, M.H.; Bien, M.Y.; Ku, C.C.; Chang, Y.C.; Pao, H.Y.; Yang, Y.L.; Hsiao, M.; Chen, C.L.; Ho, J.H. Systemic human orbital fat-derived stem/stromal cell transplantation ameliorates acute inflammation in lipopolysaccharide-induced acute lung injury. Crit Care Med. 2012, 40, 1245-1253.

111. Liang, L.; Li, W.; Ling, S.; Sheha, H.; Qiu, W.; Li, C.; Liu, Z. Amniotic membrane extraction solution for ocular chemical burns. Clin. Exp. Ophthalmol. 2009, 37, 855-863.

112. Amirjamshidi, H.; Milani, B.Y.; Sagha, H.M.; Movahedan, A.; Shafiq, M.A.; Lavker, R.M.; Yue, B.Y.; Djalilian, A.R. Limbal fibroblast conditioned media: A non-invasive treatment for limbal stem cell deficiency. Mol. Vis. 2011, 17, 658-666.

113. Geerling, G.; Maclennan, S.; Hartwig, D. Autologous serum eye drops for ocular surface disorders. Br. J. Ophthalmol. 2004, 88, 1467-1474.

114. Pflugfelder, S.C. Is autologous serum a tonic for the ailing corneal epithelium? Am. J. Ophthalmol. 2006, 142, 316-317.

115. Utheim, T.P.; Raeder, S.; Utheim, O.A.; Cai, Y.; Roald, B.; Drolsum, L.; Lyberg, T.; Nicolaissen, B. A novel method for preserving cultured limbal epithelial cells. Br. J. Ophthalmol. 2007, 91, 797-800.

116. Pasovic, L.; Utheim, T.P.; Maria, R.; Lyberg, T.; Messelt, E.B.; Aabel, P.; Chen, D.F.; Chen, X.; Eidet, J.R. Optimization of Storage Temperature for Cultured ARPE-19 Cells. J. Ophthalmol. 2013, 2013, doi:10.1155/2013/216359.

117. Pasovic, L.; Eidet, J.R.; Lyberg, T.; Messelt, E.B.; Aabel, P.; Utheim, T.P. Antioxidants Improve the Viability of Stored Adult Retinal Pigment Epithelial-19 Cultures. Ophthalmol. Ther. 2014, 3, 49-61.

118. Jackson, C.; Aabel, P.; Eidet, J.R.; Messelt, E.B.; Lyberg, T.; von Unge, M.; Utheim, T.P. Effect of storage temperature on cultured epidermal cell sheets stored in xenobiotic-free medium. PLoS ONE 2014, 9, doi:10.1371/journal.pone.0105808.

119. Islam, R.; Jackson, C.; Eidet, J.R.; Messelt, E.B.; Corraya, R.M.; Lyberg, T.; Griffith, M.; Dartt, D.A.; Utheim, T.P. Effect of storage temperature on structure and function of cultured human oral keratinocytes. PLOS ONE 2015, 10, doi:10.1371/journal.pone.0128306. 
120. Eidet, J.R.; Utheim, O.A.; Raeder, S.; Dartt, D.A.; Lyberg, T.; Carreras, E.; Huynh, T.T.; Messelt, E.B.; Louch, W.E.; Roald, B.; et al. Effects of serum-free storage on morphology, phenotype, and viability of ex vivo cultured human conjunctival epithelium. Exp. Eye Res. 2012, 94, 109-116.

121. Utheim, T.P.; Raeder, S.; Utheim, O.A.; de la Paz, M.; Roald, B.; Lyberg, T. Sterility control and long-term eye-bank storage of cultured human limbal epithelial cells for transplantation. Br. $J$. Ophthalmol. 2009, 93, 980-983.

122. O'Callaghan, A.R.; Daniels, J.T. Concise review: Limbal epithelial stem cell therapy: Controversies and challenges. Stem Cells 2011, 29, 1923-1932.

123. Ahmad, S.; Osei-Bempong, C.; Dana, R.; Jurkunas, U. The culture and transplantation of human limbal stem cells. J. Cell Physiol. 2010, 225, 15-19.

(C) 2015 by the authors; licensee MDPI, Basel, Switzerland. This article is an open access article distributed under the terms and conditions of the Creative Commons Attribution license (http://creativecommons.org/licenses/by/4.0/). 